\title{
糖尿病性血管合併症におけるインスリンと酸化ストレスについて
}

\author{
小林 恒 雄
}

\section{Possible Involvement of Insulin and Oxidative Stress in Vascular Dysfunction of Diabetic Mellitus}

\author{
Tsuneo KoBAyASHI \\ Department of Physiology and Morphology, Institute of Medicinal Chemistry, Hoshi University, \\ 2-4-41 Ebara, Shinagawa-ku, Tokyo 142-8501, Japan
}

(Received March 13, 2008)

\begin{abstract}
Macro- and microvascular disease states currently represent the principal causes of morbidity and mortality in patients with type I or type II diabetes mellitus. Abnormal vasomotor responses and impaired endothelium-dependent vasodilation have been demonstrated in various beds in different animal models of diabetes and in humans with type I or type II diabetes. The principal mediators of diabetes-associated vascular dysfunction are increases in glucose, oxidized low-density lipoprotein, endothelin-1, angiotensin II, insulin, or growth factors. An accumulating body of evidence indicates that abnormal production of oxidative stress may be one of several factors contributing to vascular dysfunction in diabetes. It is possible that in diabetic states, hyperinsulinemia initiates oxidant stress, leading to vascular dysfunction at a later stage. We and others have demonstrated that in models of hyperinsulinemia and hyperglycemia, $\cdot$ NO production and/or - NO responsiveness are impaired in aortic strips. Several recent studies have shown that the formation of nitrotyrosine and/or peroxynitrite impairs vascular $\cdot$ NO responsiveness and $\cdot$ NO production. Our findings suggest that the coexistence of a high insulin level and an established diabetic state may lead to the excessive generation of peroxynitrite, and that this may in turn trigger an impairment of endothelium-dependent relaxation via a decrease in sarcoendo plasmic reticulum $\mathrm{Ca}^{2+}$ ATPase function. This review summarizes the results of our recent studies on the involvement of insulin and oxidative stress in the blood vessels of diabetic animals.
\end{abstract}

Key words_— diabetes; oxidative stress; insulin; contraction; endothelium-dependent relaxation

\section{1. はじめに}

糖尿病は種々の合併症を誘発し患者の QOL を著 しく損ない, かつ医療費の莫大な増加の一因ともな っており，わが国においては，糖尿病になると寿命 が約 10 年短くなることが知られている。近年，日 本人のライフスタイルの変化（高脂肪食の摂取や運 動不足など）及び高齢化社会に伴い，糖尿病患者は 激増しており，もはや社会問題となりつつあり，マ スコミ誌上にもしばしば取り上げられるほどであ る。特に合併症は深刻な問題であり, 中でも網膜 症，腎症，神経症は三大合併症と呼ばれ，細小血管 障害によると考えられている，また，大血管障害の

星薬科大学医薬品化学研究所機能形態研究室 ( $142-$ 8501 東京都品川区荏原 2-4-41)

e-mail: tkoba@hoshi.ac.jp

本総説は, 平成 19 年度日本薬学会関東支部奨励賞の受 賞を記念して記述したものである。
頻度も著しく高く，その主要な症状は，冠動脈，脳 動脈，下肢動脈のアテローム性動脈硬化である。こ れら糖尿病状態における共通の合併症は，インスリ ンの絶対的不足あるいは作用の低下による高血糖状 態を中心とした各種代謝異常や, 血液学的異常から 生じた循環器障害が原因で誘発される。一方，糖尿 病時における治療効果を考える上で，インスリンに よる血糖コントロールは重要である。最近の研究で は，インスリンには血糖の低下作用のほかに様々な 作用があることが明らかになりつつある。一般的 に，糖尿病患者における正確なインスリン投与によ る血糖のコントロールは，血管合併症の進行を防ぐ が，一度発症した心血管イベントへの改善効果は少 ないと考えられている。 さらに，2 型糖尿病初期や インスリン投与によって増加する高值の血中インス リン值は，血圧や動脈硬化の悪化にも関与している ことは知られており,1) 血中のグルコース值ととも 
にインスリン值のコントロールも重要である.

糖尿病時において誘発された危険因子は，生体の 酸化ストレス増加を介して，血管障害を生じるとす る仮説は，古くから，そして現在においても多くの 研究者に指示されている。糖尿病時の酸化ストレス として，スーパーオキサイドアニオン $\left(\mathrm{O}_{2}^{-}\right)$が古 くから報告されているが，これは，高血糖，脂質， 低比重リポタンパク (LDL), 酸化 LDL, アンジオ テンシン，エンドセリンなどによって増加すること が報告されている。血管障害における酸化ストレス の 1 つである $\mathrm{O}_{2}^{-}$の増加は，血管内皮細胞から産生 される nitric oxide（NO）を不活化し，内皮細胞に おける血管弛緩機能を直接低下させることが知られ ている，そして，近年では，この $\mathrm{O}_{2}^{-}$と $\mathrm{NO}$ が反応 して産生されたパーオキシナイトライト $\left(\mathrm{ONOO}^{-}\right)$ もまた，血管弛緩機能を低下させることが報告さ れ，動脈硬化などの血管障害に強く係わつているこ とが明らかにされている。このように，糖尿病性血 管障害における酸化ストレスは，古くからそして現 在においても主要な因子として研究が進められてい る、本総説は，筆者らがこれまでに行ってきた研究 成果を中心に，糖尿病性血管合併症においてのイン スリンと酸化ストレスの因果関係を中心に紹介する.

\section{2. 糖尿病性血管内皮機能障害亡酸化ストレス}

一般的に多くの糖尿病動物において，血管弛緩反 応の低下が報告されているが，その作用機序は，様 々な条件によって異なる。糖尿病動物における減弱 した内皮依存性弛緩反応は，強力な弛緩因子である NOの合成や，その活性によって影響を受けている とは限らない。しかし，内皮依存性弛緩反応はほと んどの血管において，NO が弛緩に強く関与してい ることを考えると，やはり NOの合成や活性に焦 点が絞られる。事実，糖尿病ラット胸部大動脈にお いては，この内皮由来弛緩因子 (EDRF) としての NO の機能低下，内皮依存性弛緩反応の減弱が報告 されている $\left(\right.$ Fig 1). ${ }^{2)}$ 筆者は， 1 型， 2 型糖尿病動 物における血管内皮細胞のアセチルコリン刺激によ る弛緩反応は，様々な機序を介して糖尿病時におい て低下していることを報告している. ${ }^{2-5)}$ また， 1 型 糖尿病ラット大動脈を用いてアセチルコリン刺激時 における $\mathrm{NO}$ の代謝産物である $\mathrm{NO}_{2}^{-}, \mathrm{NO}_{3}^{-}$の測定 を行った。 その結果, 糖尿病ラットの $\mathrm{NO}_{2}^{-}+$ $\mathrm{NO}_{3}^{-}$の産生量は，コントロールラットに比べ，有

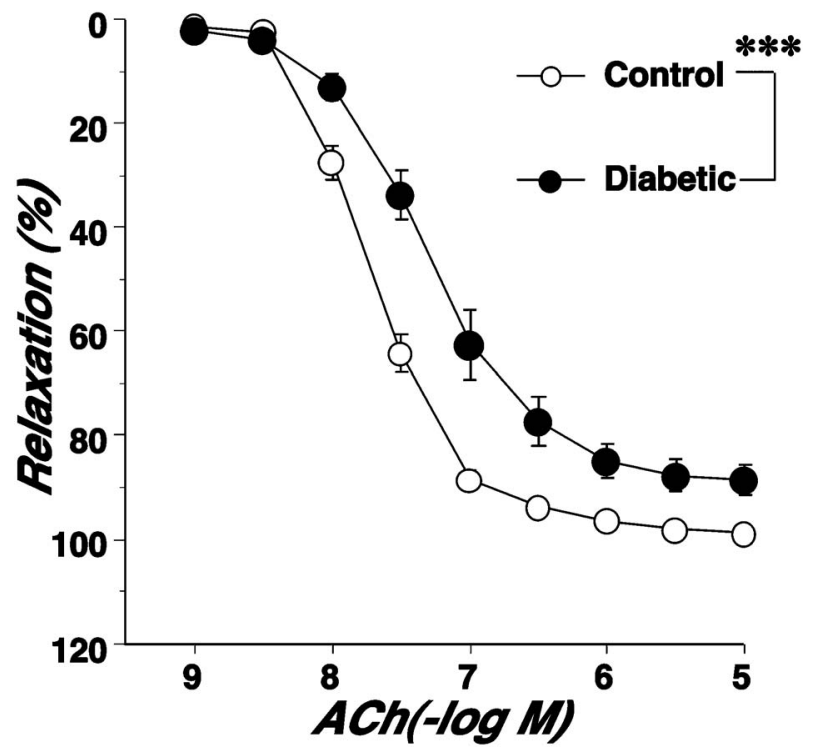

Fig. 1. Concentration-response Curves for ACh-induced relaxation of Aortic Strips Obtained from Age-matched Controls, Diabetic Rats

The ordinate shows the relaxation of aortic strips as a percentage of the contraction induced by an equieffective concentration of noradrenaline $(5 \times$ $\left.10^{-8}-3 \times 10^{-7} \mathrm{M}\right)$. Each data point represents the mean \pm S.E. of 6-8 experiments; the S.E. is included only when it exceeds the dimension of the symbol used. ${ }^{* * *} p<0.01$, diabetic vs. control.

意な差はみられなかった。このことは，内皮細胞に おける NO の産生量には変化がないことが考えら れる。ささに，構成型 NO 合成酵素である endothelial NO synthase (eNOS)の mRNA を測定した. その結果，糖尿病時においては， $\mathrm{NO}_{2}^{-}+\mathrm{NO}_{3}^{-}$の産 生量と同様に eNOS 発現も変化は認められなかっ た。また本実験において，糖尿病血管においては， $\mathrm{NO}_{2}^{-}$産生は少なく, $\mathrm{NO}_{3}^{-}$の増加が認められた。 $\mathrm{NO}$ は, 自然酸化により $\mathrm{NO}_{2}^{-}$を生じ，一方， $\mathrm{O}_{2}^{-}$ などの酸化ストレスにより $\mathrm{NO}_{3}^{-}$を生じることが知 られているので, 糖尿病時には $\mathrm{O}_{2}^{-}$の増加により NO が酸化されていると考えられる（Fig 2)，また Hink らは，糖尿病ラットの大動脈において，電子 スピン共鳴法による NO の半減期の低下と, eNOS

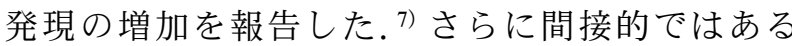
が，多くの摘出血管を用いた実験において，NO は 活性酸素 $\left(\mathrm{O}_{2}^{-}\right.$等）によって不活化されることが知 られているが， $\mathrm{O}_{2}^{-}$の scavenger である superoxide dismutase（SOD）の処置が，NO の不活化を遅延 し，糖尿病時の減弱した血管内皮機能を完全に改善 することを報告している. ${ }^{8)}$ 筆者はさらに，糖尿病 病態において，SOD の発現が低下していることを 


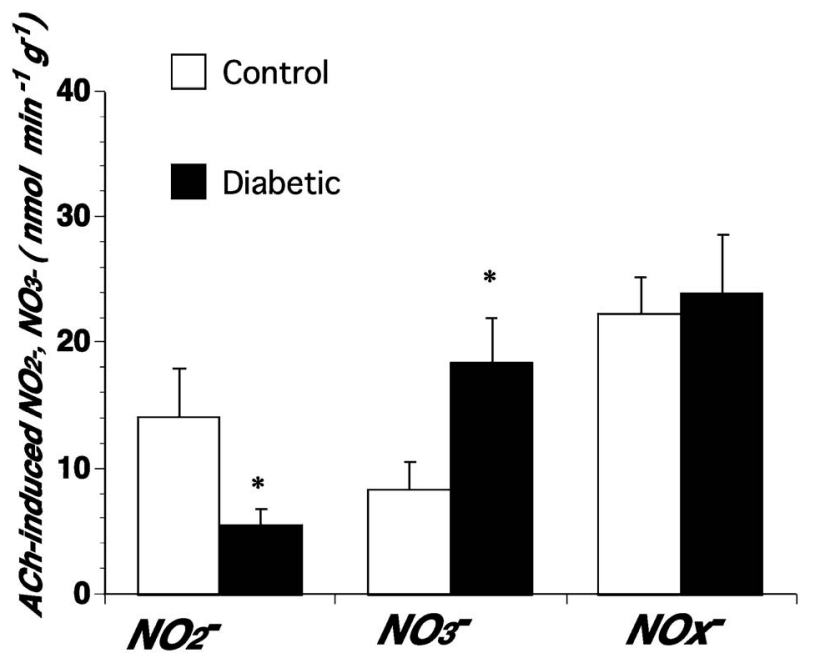

Fig. 2. ACh $\left(10^{-7}\right)$-Stimulated Release of $\mathrm{NO}_{2}^{-}, \mathrm{NO}_{3}^{-}$and NOx as Measured in the Perfusate from Aortic Strips

Each column represents the mean \pm S.E. of $6-8$ experiments. ${ }^{*} p<0.05$ diabetic vs. control.

報告し, ${ }^{9)}$ また，糖尿病時において， $\mathrm{O}_{2}^{-}$の産生増 加の原因として，NADPH oxidase の活性，及び構 成サブユニットの発現の増加によることが報告され ている. ${ }^{7)}$ 以上のことは， 1 型糖尿病時における EDRF 作用の減弱は，内皮細胞内での eNOSによ る NO の産生から平滑筋細胞内でのグアニル酸シ クラーゼまでの間に存在する，つまり NO の不活 化に焦点が絞られる。糖尿病時のこれら酸化は，生 体内における様々な細胞において認められ，血管細 胞においても例外ではなく，その1つとして， low density lipoprotein（LDL）コレステロールは，生体 内の活性酸素等により酸化され，生じた酸化 LDL は，血管内皮機能に強く作用し，NO 機能を抑制す ることが古くから知られている. ${ }^{10)} \mathrm{STZ}$ 糖尿病モデ ルにおいては，血中 LDL の増加， LDL 中の過酸化 脂質の増加，変性 LDL の酸化のし易さ，など報告 され，これらが血管内皮機能障害の原因であること が示されている. ${ }^{11)}$ さらに，われわれの経時的変化 の追跡実験では，ストレプトゾトシン（STZ）投与 後によって糖尿病の発症後 4 週間で LDL コレステ ロールの増加が生じるが，内皮機能の変化は認めら ない。しかし，10 週齡の STZ 糖尿病ラットでは, 過酸化脂質の増加と弛緩反応の減弱が生じることを

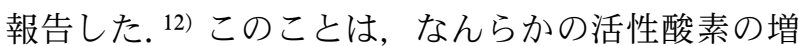
加が LDL を酸化し，また酸化された LDL は，活 性酸素を増加するような悪循環を生じていることが
考えられる。そして，活性酸素も酸化 LDL も STZ 糖尿病ラットの血管内皮機能の減弱において，強い 影響を及ぼしていることが示されている。 エンドセ リン（ET）やアンジオテンシン（Ang）は，昇圧 ペプチドであり内皮細胞由来収縮因子 (EDCF) の 1 つであるが，血管壁を含む様々な細胞にて産生さ れる．現在多くの研究がされ，これら収縮物質が内 皮細胞の弛緩因子に影響することが示され，糖尿病 血管における内皮機能についても研究が進んでい る。これら J-104132（ET $\mathrm{E}_{\mathrm{A}} / \mathrm{ET}_{\mathrm{B}}$ 受容体阻害薬）や, テモカプリル（Ang 変換酵素阻害薬）の慢性投与 は，STZ 糖尿病動物における血管内皮弛緩反応の 減弱を改善する. ${ }^{13)}$ 糖尿病ラットの血管では, NAD (P) H oxidase が過剩に発現しており，また $\mathrm{O}_{2}^{-}$の産生も著明に増加している。このラットに ET-1 の拮抗薬（J-104132）を慢性投与すると， $\mathrm{O}_{2}^{-}$ の産生が著明に低下し，内皮細胞の機能は著明に改 善する。つまり，糖尿病病態では，ET-1 が NAD (P) $\mathrm{H}$ oxidase の発現を誘導し， $\mathrm{O}_{2}^{-}$を過剩に産生 し，この $\mathrm{O}_{2}^{-}$が $\mathrm{NO}$ を不活化することによって内皮 細胞の機能を低下することになる，糖尿病病態では, $\operatorname{PPAR} \alpha, \gamma$ の発現が著明に低下しているが，ベザフ イブラートを慢性投与すると, $\operatorname{PPAR} \alpha, \gamma$ ともに増 加する．興味深いことに，ベザフィブラート慢性投 与は血中 ET-1 濃度を著明に減少するので, prepro ET-1の発現を測定したところ，著明に減少し，さ らに NAD $(\mathrm{P}) \mathrm{H}$ oxidase の過剩発現も抑制されてい た。 以上の事実から，糖尿病（1 型）では $\operatorname{PPAR} \alpha$, $\gamma$ の発現が低下し，これが ET-1 の発現を促進し， ET-1 が NAD (P) H oxidase の発現を促進し, 活性 酸素が過剩に産生されることによって内皮細胞の機 能が低下することが考えられる. ${ }^{14)}$

3. インスリンや成長因子による血管障害と活性 酸素

インスリンには血糖の低下作用のほかに様々な作 用があることが明らかになりつつある。さらにイン スリンが作用する受容体として血管細胞には，イン スリン受容体と，その他にインスリン様成長因子-1 （IGF-1）受容体が存在する. IGF-1 は，その名の通 りインスリンと似た性質を持ち，それぞれ受容体も 共有する。つまり血中に存在するインスリンは, IGF-1 受容体にも結合し，その作用をする．Bornfeldt らの報告では，インスリンによる動脈硬化誘 
導には，IGF-1 受容体を介して作用していると考え られ, ${ }^{15)}$ 近年の研究においても，その説を唱える論 文は多い。筆者の研究により，高濃度のインスリン の慢性投与による高インスリン血症は，血圧増加， 血管収縮増強作用があることが示されたが, 16) 1 つ 疑問が生じている，通常の正常動物によるインスリ ン慢性投与では，糖尿病ラットに観察された収縮, 血圧の増加を生じない（Fig. 3)。このことは，血 中に存在するインスリンの増加のみが，一連の生理 作用を生じているとは考え難い，実際，高インスリ ン血症を生じる insulinoma（インスリンを分泌す る膵島細胞腺腫）の患者においては，高血圧や動脈

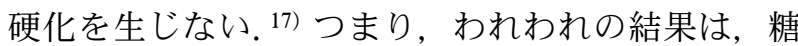
尿病状態に特異的に生じる生理学的，及び血管への 作用であることが推察され，糖尿病血管において，
IGF-1 の感受性が変化していると考えた．RT-PCR 及び Western blotting 法における IGF-1 受容体, IGF-binding protein（IGF-BP）発現を比較したと ころ，糖尿病血管において， IGF-1 受容体の増加, IGF-BP-4, -5 の低下が観察された。 IGF-BP-4 は, IGF の作用に拮抗することが報告されているの で，以上の結果は，糖尿病血管においては，IGF-1, インスリンの作用の感受性が増加していることを示 している.さらにこの発現は，インスリンを慢性投 与した糖尿病群においても改善しない。これらの結 果から，糖尿病状態，つまりインスリン欠乏や逆に 高インスリン血症状態は，血管における IGF-1 受 容体の増加，IGFBPs の低下を生じる。そしてこれ が，インスリン投与における血管収縮の増加，血圧 の増加を生じる原因であるかもしれない. ${ }^{18,19)}$ 近年

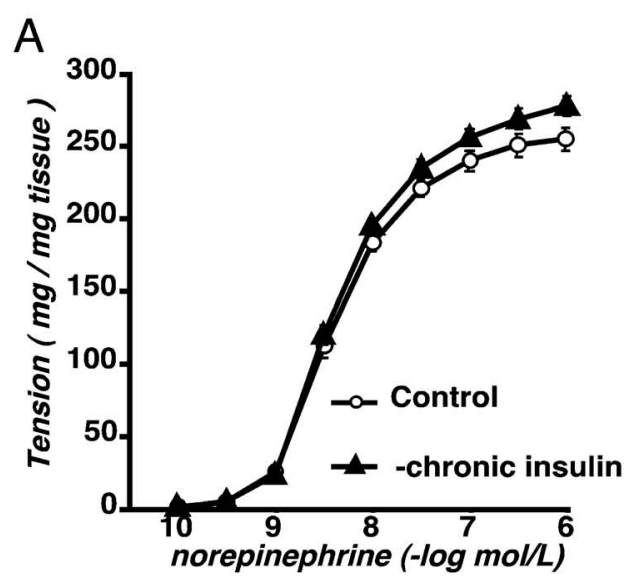

C

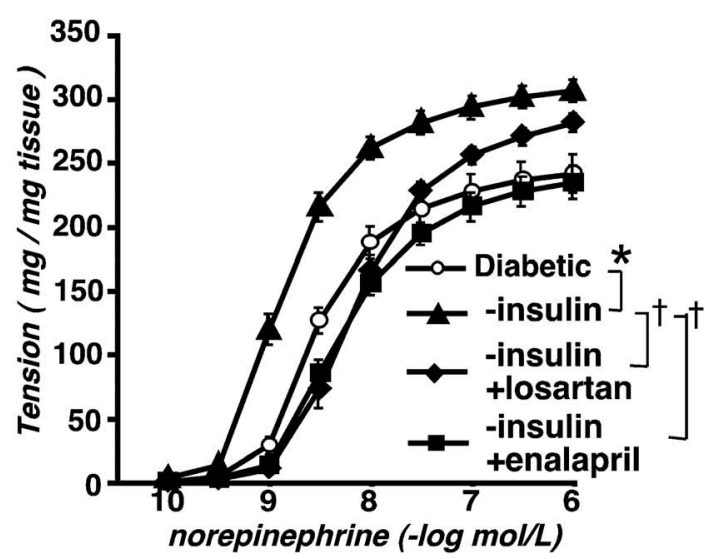

B

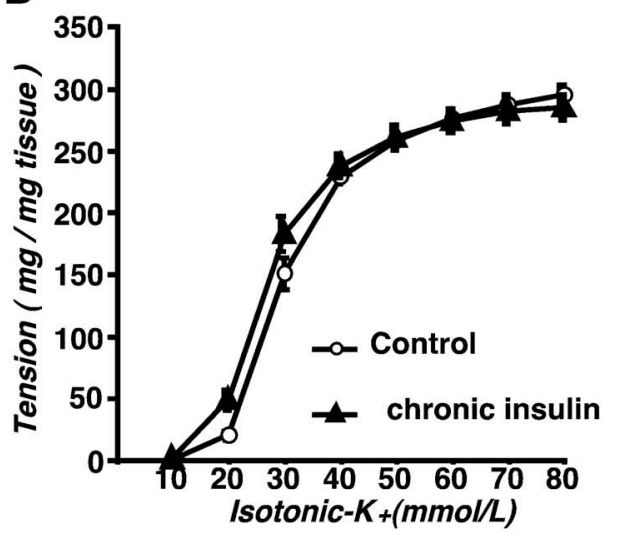

D

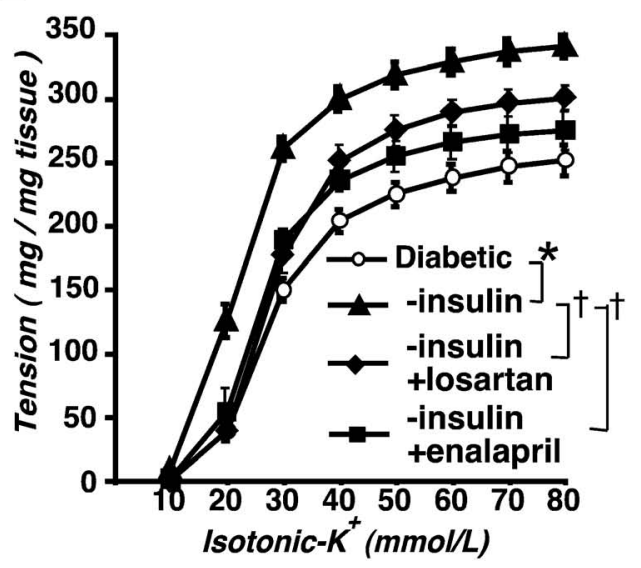

Fig. 3. Concentration-response Curves for Norepinephrine-induced (A, C) and Isotonic- $\mathrm{K}^{+}$-induced (B, D) Contractions in Endothelium-denuded Strips of Rat Aortas

The strips were obtained from: (A, B) age-matched controls, and (C, D) untreated diabetic rats, and chronic insulin-treated (insulin), insulin + losartan-treated (insulin + losartan), or chronic insulin + enalapril-treated (insulin + enalapril) diabetic rats. Ordinate shows increase in tension (expressed in mg tension $\mathrm{mg}$ tissue $^{-1}$ ) measured at the peak of the response. Each data-point represents the mean \pm S.E. from $8-10$ experiments; the S.E. is included only when it exceeds the dimension of the symbol used. ${ }^{*} p<0.05$, insulin-treated vs. untreated diabetic. ${ }^{*} p<0.05$, vs. insulin-treated diabetic. 
のヒト内皮細胞の培養実験によって，インスリンに は，NO の産生促進作用，NO 合成酵素（NOS）発

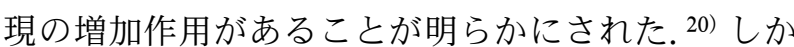
し一方では，ラットへの外因的な高インスリン血症 は，胸部大動脈の $\mathrm{O}_{2}^{-}$を増加することも報告され た. ${ }^{21)}$ さらに培養細胞においては，インスリンは, NADPH oxidase を活性化し， $\mathrm{O}_{2}^{-}$を増加すること が報告された. ${ }^{22)}$ また，この $\mathrm{O}_{2}^{-}$の増加には，PI3kinase が関与していることが報告され，インスリンPI3-kinase-NADPH oxidase- $\mathrm{O}_{2}^{-}$増加の一連の pathway が存在することが考えられる，最近筆者は，高 インスリン血症ラットにおいて，PI3-kinase の subunit である $\mathrm{p} 110 \delta$ タンパク発現の増加によって, PI3-kinse 活性が増加していることを報告した。 ${ }^{23)}$ さらに，この高インスリン血症動物において，血中 の Ang II 増加が認められ，Ang type I-受容体阻害 薬である losartan 慢性投与によって，PI3-kinase の 活性増加の低下が認められた（Fig. 4)。つまり， 生体内においては，高インスリン血症は，直接作用 だけではなく，Ang IIなどの他の因子を介して，酸

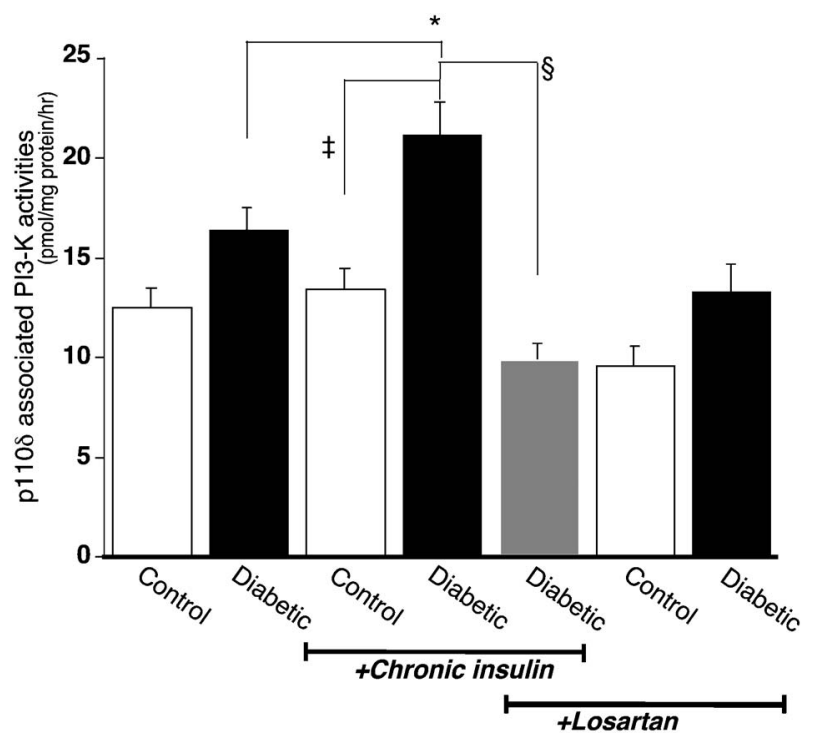

Fig. 4. p110-associated PI3-K Activity Levels following Norepinephrine (NE)-stimulation in Aortas from Control, Diabetic, Insulin-treated Control (Control + Chronic insulin), Insulin-treated Diabetic (Diabetic + Chronic insulin), Insulin + losartan-treated Diabetic (Diabetic + Chronic insulin + Losartan), and Losartan-treated Control or Diabetic (+losartan) Rats

All aortic strips were stimulated with $\mathrm{NE}\left(10^{-8} \mathrm{~mol} / \mathrm{l}\right)$ for $5 \mathrm{~min}$. The aortic lysate was immunoprecipitated with p110 antibody. Amount of PIP3 produced by PI3-K was detected using a competitive ELISA.. Values are each the mean \pm S.E. from 8 determinations. ${ }^{*} p<0.05$, insulin-treated vs. untreated diabetic. ${ }^{*} p<0.05$, insulin-treated diabetic $v s$. insulin-treated control. \& $p<0.05$, insulin-treated vs. insulin + losartan-treated diabetic.
化ストレスを増加している可能性は高い.

\section{4. インスリンによる血管内皮機能障害と $\mathrm{ONOO}^{-}$} の関与

2 型糖尿病時の初期や，糖尿病時のインスリン処 置時には，高インスリン血症が生じ，その結果酸化 ストレスによる血管障害を生じる可能性がある。一 般的に血管内皮細胞におけるインスリンの効果は, インスリン受容体，PI3-K/Akt などを介し NO 合 成酵素を活性化し，NO 産生をすることによって血 管弛緩作用を有する。フルクトースを慢性的に負荷 することによって作成するフルクトース負荷モデル は，高インスリン血症，インスリン抵抗を生じ，比 較的安易に作成できる動物モデルとして報告されて

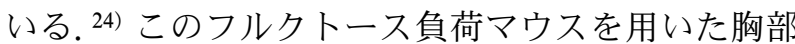
大動脈において，アセチルコリンの弛緩反応の減弱 が報告され，またアセチルコリン刺激によって産生 されるNOx 量も低下が認められた。しかし，クロ ニジンによる $\alpha_{2}-$ 作動薬による内皮依存性弛緩反応 と NO 産生は，アセチルコリン刺激と異なり，フ ルクトース負荷マウスにおいて増加している. ${ }^{25)} こ$ の実験と同様に, 自然発症 2 型糖尿病モデルの GK ラットにおいて，初期時の 12 週齡では，胸部大動 脈 $\alpha_{2 \mathrm{D}}$-受容体の mRNA 発現増加と作動薬刺激によ る NOx 産生の増加が認められたが，36 週齢では

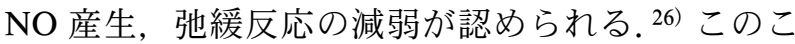
とから，糖尿病初期に認められるインスリンによる 過剩な NO 産生は，血管障害の重要な因子である と考えられる。また，Pieper らは，初期の糖尿病 状態において，NO scavengerであるNOX101 を慢 性投与することによって，終期の血管弛緩反応の減 弱を予防できることを報告している. ${ }^{27)}$ 先の記述の ように，糖尿病には多くの因子によって $\mathrm{O}_{2}^{-}$は増加 する。つまり，糖尿病時には，過剩な $\mathrm{O}_{2}^{-}$と $\mathrm{NO}$ が 反応し， $\mathrm{ONOO}^{-}$を生じることによって，血管障 害を生じている仮説が考えられる，最近の研究では，

$\mathrm{ONOO}^{-}$は直接の作用により, $\mathrm{NO}$ 産生, NO の平 滑筋への弛緩機能の障害をすることによって，血管 内皮細胞依存性の弛緩反応を減弱することが報告さ れた．特に興味深い研究として，高脂血症動物にお いて, $\mathrm{ONOO}^{-}$の増加によって，血管平滑筋細胞 における筋小胞体 Ca-ATPase（SERCA）を阻害す ることによって，細胞内カルシウムの低下が抑制さ れ，弛緩反応が減弱することが報告されている. ${ }^{28)}$ 
さらに，筆者は糖尿病ラット胸部大動脈の器官培養 法を用いて，インスリンによる $\mathrm{ONOO}^{-}$の増加に

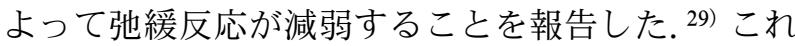
は，糖尿病血管においては，インスリンによって過 唾な $\mathrm{O}_{2}^{-}$と $\mathrm{NO}$ が産生し，その結果生じる $\mathrm{ONOO}^{-}$ が増加する。この $\mathrm{ONOO}^{-}$は SERCA をニトロ化 し，平滑筋のカルシウム取り込みを阻害することに よって, 内皮細胞依存性の弛緩機能障害を生じるこ とを報告した（Fig. 5)。この実験の興味深い点と して，正常動物より摘出した血管においては，イン スリンは，弛緩反応， $\mathrm{ONOO}^{-}$の増加に関与して いないことである（Fig. 6)。このことは，糖尿病 時においてのみ，インスリンの高濃度の状態が続く と血管障害を誘発する可能性を裏付けている。さら に，糖尿病ラットに，Ang 変換酵素阻害薬である enalapril を慢性投与すると，糖尿病時における弛 緩反応の減弱は改善し, SERCA 機能の改善,

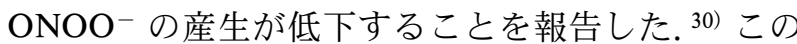
ことから，糖尿病時には，Ang II もまた， ONOOの増加を生じ血管機能を傷害する可能性を示してい る.

\section{5. おわりに}

インスリンは，生理的条件下で血糖值を下げるほ とんど唯一のホルモンである。糖尿病は，インスリ ンの作用不足により高血糖を来たす症候群であり，

同時に糖尿病合併症の予防においても, 血糖值を低 下させることが主要である。しかし，この血糖值の コントロールは非常に難しく，さらに，血糖值だけ では，血管合併症を予防することはできないとされ ている。 この血糖值以外の因子についても，われわ
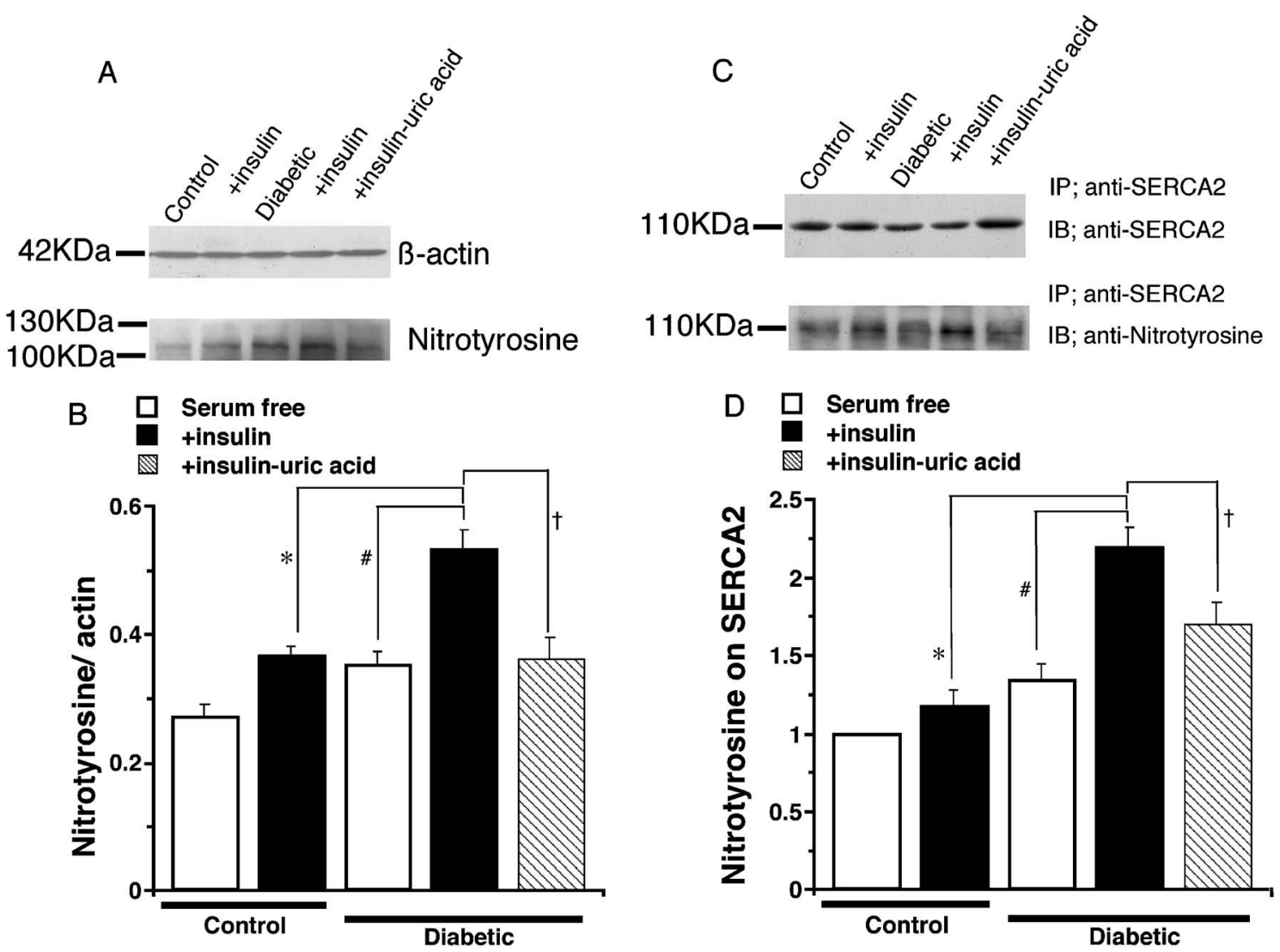

Fig. 5. Expression of Nitrotyrosine (A, B) or Nitrotyrosine in SERCA2 Protein (C, D) in Aortic Strips Cultured either in Serum-free Medium or in the Presence of Insulin with or without Uric Acid

Strips obtained from controls and diabetic rats were cultured in one of three ways: in serum-free medium, in the presence of insulin alone $(+\mathrm{insulin})(50 \mathrm{ng} /$ $\mathrm{ml}$ ), or in the presence of insulin plus uric acid $(0.5 \mathrm{mM})$ (+insulin + uric acid). (A, B), Expression of nitrotyrosine assayed by immunoblotting (IB). (C, D), For detection of nitrotyrosine in SERCA protein (C, top), an immunoprecipitate (IP) was obtained using anti-SERCA2 antibody, then immunoblotted with anti-SERCA2 antibody. (C, bottom), an IP was obtained using anti-SERCA2 antibody, then immunoblotted with anti-nitrotyrosine antibody. (B, D), Quantitative analysis of nitrotyrosine by scanning densitometry. Control or diabetic aortas in serum-free medium (open columns), with insulin (closed columns), or with insulin plus uric acid (hatched columns). Each value is mean + S.E. from $6-8$ experiments. ${ }^{*} p<0.05$ vs. control aortas cultured in presence of insulin. ${ }^{*} p<0.05$ vs diabetic aortas cultured in serum-free medium. ${ }^{*} p<0.05$ vs. diabetic aortas cultured in presence of insulin. 
A

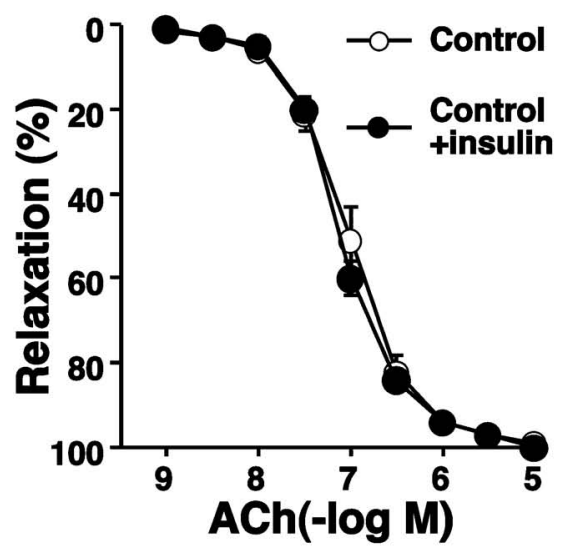

B
C

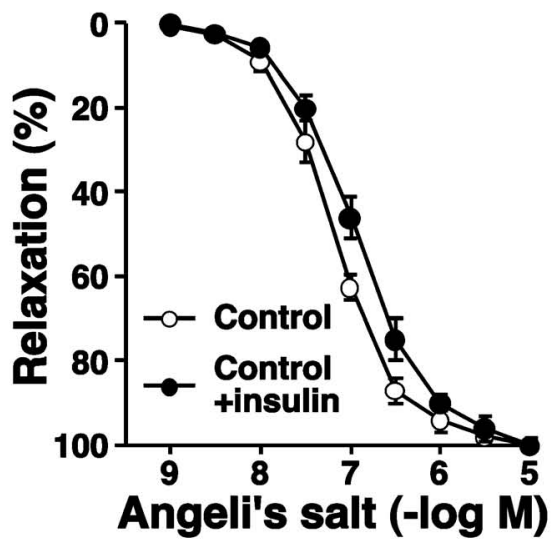

D
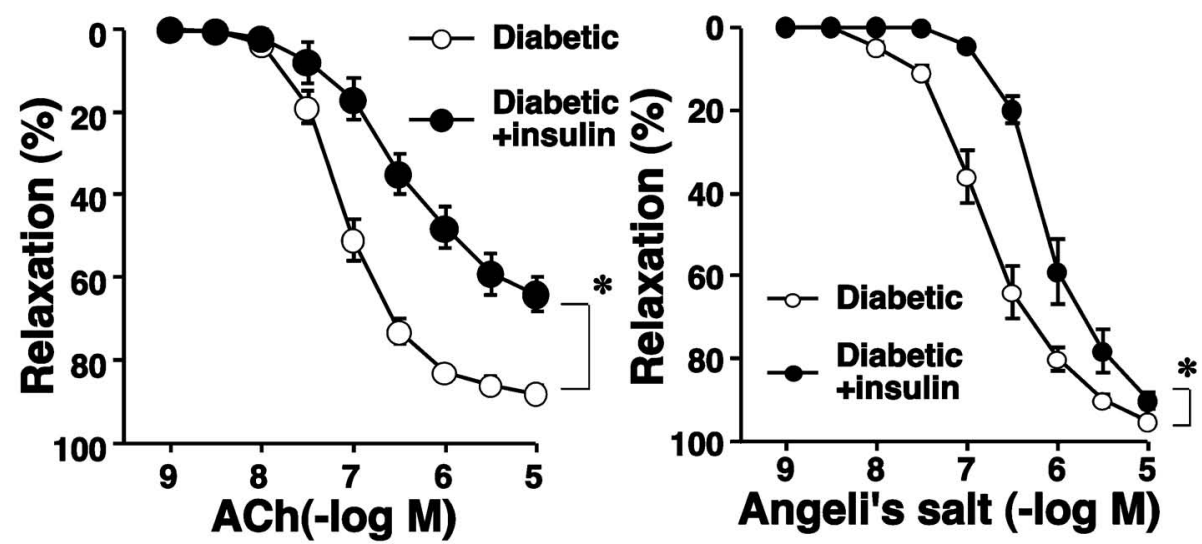

Fig. 6. Concentration-response Curves for the ACh (A, B) - and Angeli's Salt (C, D) -induced Relaxations of Aortic Strips after Organ Culture

Strips obtained from control rats (A, C) and diabetic rats (B, D) were cultured in serum-free medium or in the presence of insulin $(50 \mathrm{ng} / \mathrm{ml}) \mathrm{In}$ C and D, the endothelium was removed after culture. Ordinates show relaxation as a percentage of the contraction induced by an equieffective concentration of $\mathrm{NE}\left(10^{-8}-5 \times\right.$ $10^{-8} \mathrm{M}$ ). Each data-point represents the mean + S.E. from 8-10 experiments (S.E. is included only when it exceeds the dimension of the symbol used). ${ }^{*} p<0.05 \mathrm{vs}$. diabetic aortas cultured in serum-free medium.

れを含め多くの研究者が検討を行っている。中で も，本総説のインスリンによる血管への影響は，他 の因子に比べ作用が強いのではないだろうか.イン スリンは，自身が成長因子であるとともに，様々な 成長因子を誘導する．特に，血中インスリン值，及 びインスリン動態が正常值ではない状態，つまり糖 尿病時において，明らかに異常が認められた。糖尿 病時の血管においてのみ，血圧，血管収縮力の増加， $\alpha_{1}$-受容体の増加, $\mathrm{ONOO}^{-}$の増加, SERCA のニ トロ化の増加，弛緩機能の低下が認められた（Fig. 7)。また注意しなくてはならないのは，血管を $1 つ$ の器官として捉えたとき，インスリンによる血管に “よい”“悪い”作用が，それぞれにおいて相反する 作用をし，強い作用がトータルの血管の作用として 現れていることである。このバランスの乱れがどの

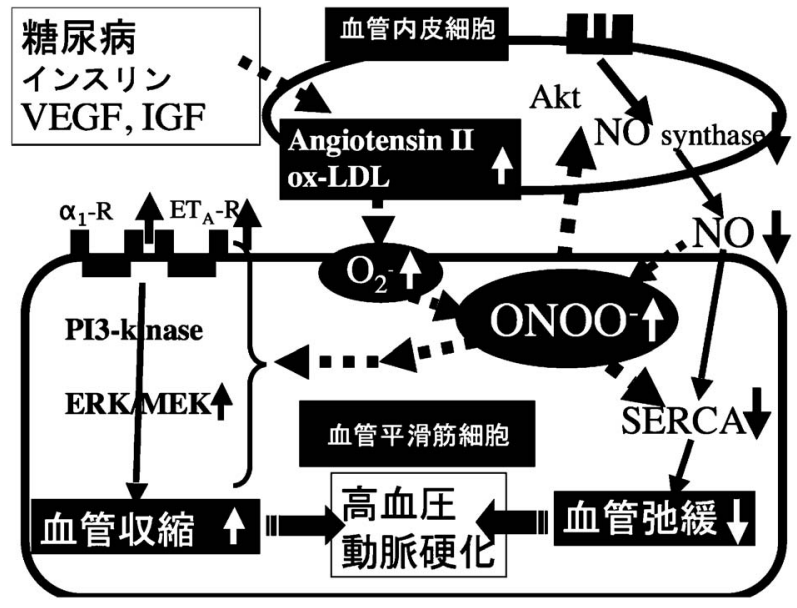

Fig. 7. Scheme Showing the Sequence Described in the Text between Insulin and Oxidative Stress Production (leading to vascular dysfunction) in Diabetes 
ように血管合併症において作用するのかいまだ明ら かではないが，このことが最も重要であるのかもし れない，その 1 つとして古くから研究が盛んな酸化 ストレスが原因であり，この酸化ストレスを増加さ せる因子も Ang，高血糖，LDL など古くから報告 がある因子がメインになり，連鎖することによって 糖尿病性血管障害を生じていると考えられる。今 後，これらの不明な点を明らかにしていくことで， 糖尿病性血管合併症の発症機序，予防薬の開発が進 んでいくことを期待する.

\section{謝辞本研究は, 星薬科大学機能形態研究室で} 行われた研究であり，終始，御指導頂きました鎌田 勝雄教授に心から感謝申し上げます。また，本研究 を行うに当たり，御協力と御助言賜りました，松本 助教，並びに同研究室の皆様に深く感謝いたします。

\section{REFERENCES}

1) Standley P. R., Bakir M. H., Sowers J. R., Am. J. Kidney Dis., 21, 39-46 (1993).

2) Kobayashi T., Matsumoto T., Kamata K., $J$. Smooth Muscle Res., 41, 283-302 (2005).

3) Kobayashi T., Oishi K., Hayashi Y., Matsumoto T., Kamata K., Atherosclerosis, $\mathbf{1 8 5}$, 47-57 (2006) .

4) Kobayashi T., Taguchi K., Yasuhiro T., Matsumoto T., Kamata K., Hypertension, 44, 956-962 (2004).

5) Kobayashi T., Kamata K., Am. J. Physiol. Heart Circ. Physiol., 283, H1761-H1768 (2002).

6) Kobayashi T., Kamata K., Atherosclerosis., 155, 313-320 (2001).

7) Hink U., Li H., Mollnau H., Oelze M., Matheis E., Hartmann M., Skatchkov M., Thaiss F., Stahl R. A., Warnholtz A., Meinertz T., Griendling K., Harrison D. G., Forstermann U., Munzel T., Circ. Res., 88, E14-E22 (2001).

8) Tesfamariam B., Free Radic. Biol. Med., 16, 383-391 (1994).

9) Kamata K., Kobayashi T., Br. J. Pharmacol., 119, 583-589 (1996).

10) Kugiyama K., Kerns S. A., Morrisett J. D., Roberts R., Henry P. D., Nature, 344, 160162 (1990).
11) Kobayashi T., Matsumoto T., Kamata K., Br. J. Pharmacol., 131, 231-238 (2000).

12) Kobayashi T., Kamata K., Eur. J. Pharmacol., 367, 213-222 (1999).

13) Pieper G. M., Siebeneich W., Eur. J. Pharmacol., 403, 129-132 (2000).

14) Kanie N., Matsumoto T., Kobayashi T., Kamata K., Br. J. Pharmacol., 140, 23-32 (2003).

15) Bornfeldt K. E., Arnqvist H. J., Capron L., Diabetologia, 35, 104-108 (1992).

16) Kobayashi T., Kamata K., Br. J. Pharmacol., 127, 835-842 (1999).

17) Hall J. E., Brands M. W., Zappe D. H., Galicia M. A., Proc. Soc. Exp. Biol. Med., 208, 317-329 (1995).

18) Kobayashi T., Kaneda K., Kamata K., Br. $J$. Pharmacol., 140, 285-294 (2003).

19) Kobayashi T., Matsumoto T., Kamata K., $J$. Endocrinol., 186, 367-376 (2005).

20) Kuboki K., Jiang Z. Y., Takahara N., Ha S. W., Igarashi M., Yamauchi T., Feener E. P., Herbert T. P., Rhodes C. J., King G. L., Circulation, 101, 676-681 (2000).

21) Kashiwagi A., Shinozaki K., Nishio Y., Maegawa H., Maeno Y., Kanazawa A., Kojima H., Haneda M., Hidaka H., Yasuda H., Kikkawa R., Am. J. Physiol., 277, E976-E983 (1999) .

22) Ceolotto G., Bevilacqua M., Papparella I., Baritono E., Franco L., Corvaja C., Mazzoni M., Semplicini A., Avogaro A., Diabetes, 53, 1344-1351 (2004).

23) Kobayashi T., Hayashi Y., Taguchi K., Matsumoto T., Kamata K., Am. J. Physiol. Heart Circ. Physiol., 291, H846-H853 (2006) .

24) Reaven G. M., Diabetes Care, 14, 195-202 (1991).

25) Kamata K., Kanie N., Inose A., Eur. J. Pharmacol., 428, 241-249 (2001).

26) Kobayashi T., Matsumoto T., Ooishi K., Kamata K., Am. J. Physiol. Heart Circ. Physiol., 287, H135-H143 (2004).

27) Pieper G. M., Dembny K., Siebeneich W., Diabetologia, 41, 1220-1226 (1998).

28) Adachi T., Matsui R., Xu S. Q., Kirber M., Lazar H. L., Sharov V. S., Schoneich C., Cohen R. A., Circ. Res., 90, 1114-1121 (2002).

29) Kobayashi T., Taguchi K., Takenouchi Y., 
Matsumoto T., Kamata K., Free Radic. Biol. Med., 43, 431-443 (2007).

30) Taguchi K., Kobayashi T., Hayashi Y., Mat- sumoto T., Kamata K., Eur. J. Pharmacol., 556, 121-128 (2007). 